\title{
HUBUNGAN KEPERCAYAAN DIRI TERHADAP KEMAMPUAN PENALARAN MATEMATIS SISWA SMP
}

\author{
Eneng Eni Zahrotul Aeni ${ }^{1}$, Irma Nurfahriani ${ }^{2}$, Gida Kadarisma ${ }^{3}$ \\ 1,2,3 IKIP Siliwangi, Jl. Terusan Jend. Sudirman Kb. Rumput Cimahi \\ 1Zahrotulaeni22@gmail.com, ${ }^{2}$ Irmanurfahriani123@gmail.com, ${ }^{3}$ gidakadarisma@ikipsiliwangi.ac.id,
}

\begin{abstract}
This research aims to examine how the correlation of self-confidence to the ability of mathematical reasoning of Junior High School student. The type of reseach used is correlational research. The subject of research is the students of class IX SMP Negeri 2 Ngamprah. Data collection techniques in this research is a test of mathematical reasoning ability in the form of description and self-confidence questionnaire. The results of the indicate a significant relationship between self-confidence and mathematical reasoning ability of junior high scool students.
\end{abstract}

Keywords: Self-Confidence, Mathematical Reasoning Ability

\begin{abstract}
Abstrak
Penelitian ini bertujuan untuk menelaah bagaimana hubungan kepercayaan diri (self confidence) terhadap kemampuan penalaran matematis siwa SMP. Jenis penelitian yang digunakan adalah penelitian korelasional. Subjek penelitian adalah siswa kelas IX SMP Negeri 2 Ngamprah. Teknik pengumpulan data pada penelitian ini adalah tes kemampuan penalaran matematis dalam bentuk uraian dan angket kepercayaan diri (self confidence). Hasil penelitian menunjukkan adanya hubungan yang signifikan antara kepercayaan diri dan kemampuan penalaran matematis siswa SMP.
\end{abstract}

Kata Kunci: Kata kunci: kepercayaan diri (self confidence), kemampuan penalaran matematis

How to cite: Aeni, E. E. Z., Nurfahriani, I., \& Kadarisma, G. (2018). Hubungan Kepercayaan Diri terhadap Kemampuan Penalaran Matematis Siswa SMP. JPMI - Jurnal Pembelajaran Matematika Inovatif, 1 (4), 531-538.

\section{PENDAHULUAN}

Kemampuan Pendidikan merupakan bagian terpenting dalam aspek kehidupan sebagai bekal dalam rangka membentuk manusia yang cerdas dan berkualitas. Fungsi pendidikan secara lengkap terangkum dalam bab 2 pasal 3 UU. No.20 tahun 2003 (Jati, 2012) tentang sistem pendidikan nasional yang berbunyi sebagai berikut: Pendidikan Nasional berfungsi mengembangkan kemampuan dan membentuk watak serta peradaban bangsa yang bermartabat dalam rangka mencerdaskan kehidupan bangsa, bertujuan berkembangnya potensi peserta didik agar menjadi manusia yang beriman dan bertakwa kepada Tuhan Yang Maha Esa, berakhlak mulia, sehat, berilmu, sakap, kreatif, mandiri, dan menjadi warga negara yang demokratis serta bertanggung jawab.

Pembelajaran di sekolah turut andil dalam mencerdaskan kehidupan bangsa. Salah satu mata pelajaran yang memberikan konstribusi positif dalam mencerdaskan kehidupan bangsa adalah 
matematika (Hartono, 2010). Matematika memilki peranan penting dalam perkembangan ilmu pengetahuan dan teknologi. Matematika dan pembelajaran merupakan dua hal yang tidak dapat dipandang secara parsial, keduanya saling berkaitan satu sama lain (Kadarisma, 2016). Agar dapat mengikuti perkembangan ilmu pengetahuan dan teknologi tersebut, diperlukan aspek penting yang harus dimiliki siswa yaitu kepercayaan diri (self confidence) dan kemampuan penalaran yang baik (Sumarmo, Mulyani, \& Hidayat, 2018; Tresnawati, Hidayat, \& Rohaeti, 2017).

Menurut Lauster (Hendriana, Rohaeti, \& Sumarmo, 2017), kepercayaan diri merupakan suatu sikap atau perasaan yakin atas kemampuan diri sendiri sehingga orang yang bersangkutan tidak terlalu cemas dengan tindakan-tindakannya, dapat merasa bebas untuk melakukan hal yang disukainya, dan bertanggung jawab atas tindakannya, hangat dan sopan dalam berinteraksi dengan orang lain, dapat menerima dan menghargai orang lain, memiliki dorongan untuk berprestasi serta mengenal kelebihan dan kekurangan dirinya. Pentingya kepercayaan diri sebagaimana yang di kemukakan oleh Yates (Hendriana, Rohaeti \& Sumarmo, 2017) bahwa kepercayaan diri sangat penting bagi siswa agar berhasil dalam belajar matematika. Dengan adanya rasa percaya diri, siswa akan lebih termotivasi dan lebih menyukai belajar matematika, sehingga pada akhirnya diharapkan prestasi belajar matematika yang dicapai juga lebih optimal. Artinya siswa yang memiliki hasil belajar matematika tinggi juga memiliki indeks kepercayaan diri yang tinggi pula.

Selain kepercayaan diri, Penalaran matematis juga merupakan hal yang sangat penting dalam proses pembelajaran matematika (Hermawan \& Hidayat, 2018; Hidayat, 2017; Hidayat \& Prabawanto; 2018; Isnaeni, Fajriyah, Risky, Purwasih, \& Hidayat, 2018; Sholihat, Hidayat, \& Rohaeti, 2018; Yusdiana \& Hidayat, 2018). Kemampuan penalaran matematik adalah kemampuan yang dapat membentuk pola pikir seseorang (Hidayat, 2017). Karena matematika merupakan ilmu pengetahuan yang diperoleh melalui bernalar. Sejalan dengan hal tersebut Ruseffendi (Mikrayanti, 2016) menyatakan bahwa matematika terbentuk sebagai hasil pemikiran manusia yang berhubungan dengan ide, proses dan penalaran. Pentingnya memiliki kemampuan penalaran matematis pada dasarnya sejalan dengan visi matematika khususnya untuk memenuhi kebutuhan masa datang. Sehubungan dengan itu, Sumarmo (Hendriana et al., 2017) mengemukakan bahwa pembelajaran matematika diarahkan untuk memberi peluang untuk berkembangnya kemampuan bernalar, kesadaran terhadap kebermanfaatan matematika, menumbuhkan rasa percaya diri, sikap objektif dan terbuka untuk menghadapi masa depan yang selalu berubah. Sejalan dengan pendapat tersebut Baroody (Hendriana et al., 2017) menyatakan bahwa penalaran matematis sangat penting dalam membantu individu tidak sekedar mengingat fakta, aturan, dan langkah-langkah penyelesaian masalah, tetapi menggunakan keterampilan bernalarnya dalam melakukan pendugaan atas dasar pengalamannya sehingga yang bersangkutan akan memperoleh pemahaman konsep matematika yang saling berkaitan dan belajar secara bermakna.

Namun pada kenyataannya kedua hal tersebut masih tergolong rendah, hal ini dibuktikan oleh hasil penelitian dari Third International Mathematics and Science Study (TIMSS) dalam (Fitriani, 2016) Menunjukkan rendahnya self confidence siswa Indonesia yaitu sekitar dibawah $30 \%$. Penelitian lain juga menunjukkan kurangnya kemampuan matematika siswa yang dilihat dari kinerja dalam bernalar, misalnya masih banyak siswa mengalami kesulitan dalam menyelesaikan soal matematika, sebagaimana diungkapkan Wahyudin (Mikrayanti, 2016) salah satu penyebab sejumlah siswa gagal menguasai pokok-pokok bahasan matematika yaitu karena mereka kurang menggunakan nalar yang logis dalam menyelesaikan soal atau persoalan matematika yang diberikan. Siwa seringkali merasa kesulitan dalam memahami materi 
dikarenakan siswa hanya menghafal rumus dan pembelajaran yang dibawakan oleh guru masih prosedural (Putri, Nursyahban, Kadarisma, \& Rohaeti, 2018), kesulitan-kesulitan siswa tersebut diakibatkan keterbatasan konteks yang dimiliki oleh siswa, siswa dibiasakan mendapat soal yang rutin sehingga diberikan soal yang sedikit kompleks ia tidak bisa mengerjakannya (Rismawati, Nurlitasari, Kadarisma, \& Rohaeti, 2018). Tujuan penelitian ini adalah menelaah bagaiman pengaruh kepercayaan diri terhadap kemampuan penalaran matematis siswa SMP. Manfaat penelitian ini adalah sebagai informasi untuk membantu guru dalam mengukur kepercayaan diri siswa saat menyelesaikan soal kemampuan penalaran.

\section{METODE}

Metode dalam penelitian ini adalah metode korelasional. Faenkel dan Wallen (Annisa, 2010) mengemukakan bahwa penelitian korelasi atau korelasional adalah suatu penelitian untuk mengetahui hubungan dan tingkat hubungan antara dua variabel atau lebih tanpa ada upaya untuk mempengaruhi variabel tersebut sehingga tidak terdapat manipulasi variabel. Subjek penelitian ini adalah siswa kelas IX SMP Negeri 2 Ngamprah. Instrumen yang digunakan adalah instrumen tes kemampuan penalaran matematis dan angket kepercayaan diri (self confidence).

\section{HASIL DAN PEMBAHASAN}

\section{Hasil}

Hipotesis dalam penelitian ini adalah terdapat hubungan yang signifikan dari kepercayaan diri terhadap kemampuan penalaran matematis siswa SMP. Untuk menguji hipotesis tersebut, maka dilakukan uji korelasi. Sebelum menguji korelasi terlebih dahulu dilakukan uji normalitas sebagai prasyarat, jika data berdistribusi normal maka dilanjutkan dengan uji korelasi Product Moment Pearson dan jika tidak berdistribusi normal maka digunakan uji korelasi Spearman.

Uji normalitas data

Hipotesis yang akan diuji:

H0: Data penalaran matematis dan kepercayaan diri berdistribusi normal

H1: Data penalaran matematis dan kepercayaan diri tidak berdistribusi normal

Kriteria pengambilan keputusan uji normalitas adalah sebagai berikut:

1). Jika nilai signifikasi lebih kecil dari 0,05 maka $\mathrm{H} 0$ ditolak

2). Jika nilai signifikasi lebih besar sama dengan 0,05 maka H0 diterima

Berikut ini hasil dari uji normalitas:

Tabel 1. Hasil Uji Normalitas Penalaran Matematis dan Kepercayaan diri

\begin{tabular}{llll}
\hline & & \multicolumn{2}{l}{ Kepercayaan diri $\begin{array}{l}\text { Kemampuan } \\
\text { matematis }\end{array}$} \\
\hline $\mathrm{N}$ & & 29 & 29 \\
Normal & Mean & 98,28 & 11,62 \\
Parameters ${ }^{\mathrm{a}, \mathrm{b}}$ & Std. Deviation & 10,064 & 2,796 \\
Most ExtremeAbsolute &, 089 &, 170 \\
Differences & Positive &, 074 &, 170 \\
& Negative &,- 089 &,- 114 \\
\multicolumn{2}{l}{ Test Statistic } &, 089 &, 170 \\
Asymp. Sig. (2-tailed) &, $200^{\mathrm{c}, \mathrm{d}}$ &, $031^{\mathrm{c}}$ \\
\hline
\end{tabular}

Dari Tabel 1 diatas, ternyata nilai signifikasi uji Kolmogorov Smirnov pada skor tes kemampuan penalaran matematis yaitu 0,200 maka $\mathrm{H0}$ diterima, namun untuk skor 
kepercayaan diri sisiwa yaitu 0,031 maka H0 ditolak. Artinya data skor kemampuan penalaran matematis dan kepercayaan diri siswa tidak berdistribusi normal. Pada perhitungan sebelumnya telah diketahui bahwa data skor kemampuan penalaran matematis dan kepercayaan diri siswa tidak berdistribusi normal. Maka untuk mengetahui pengaruh kepercayaan diri terhadap kemampuan penalaran matematis digunakan uji korelasi spearman dengan taraf signifikansi 0,05 .

Hipotesis yang akan diuji:

H0: Tidak terdapat hubungan yang signifikan antara kepercayaan diri dan kemampuan penalaran matematis siswa.

H1: Terdapat hubungan yang signifikan antara kepercayaan diri dan kemampuan penalaran matematis siswa

Kriteria pengambilan keputusan uji normalitas adalah sebagai berikut:

1). Jika nilai signifikasi lebih kecil dari 0,05 maka $\mathrm{H} 0$ ditolak

2). Jika nilai signifikasi lebih besar sama dengan 0,05 maka H0 diterima

Hasil pengolahan korelasi ditunjukkan pada tabel berikut:

Tabel 2. Hasil Uji Korelasi antara Kepercayaan Diri dan Kemampuan

\begin{tabular}{|c|c|c|c|c|}
\hline & & Kepercayaan diri & $\begin{array}{l}\text { Kemampuan } \\
\text { matematis }\end{array}$ & penalaran \\
\hline \multirow[t]{3}{*}{$\begin{array}{l}\text { SpearmKepercayaan } \\
\text { an's rhodiri }\end{array}$} & $\begin{array}{l}\text { Correlation } \\
\text { Coefficient }\end{array}$ & 1,000 &, $509^{* *}$ & \\
\hline & Sig. (2-tailed) & - &, 005 & \\
\hline & $\mathrm{N}$ & 29 & 29 & \\
\hline \multirow{3}{*}{$\begin{array}{l}\text { Kemampuan } \\
\text { penalaran } \\
\text { matematis }\end{array}$} & $\begin{array}{l}\text { Correlation } \\
\text { Coefficient }\end{array}$ &, $509^{* *}$ & 1,000 & \\
\hline & Sig. (2-tailed) &, 005 & . & \\
\hline & $\mathrm{N}$ & 29 & 29 & \\
\hline
\end{tabular}

Dari Tabel 2, diperoleh hasil bahwa kepercayaan diri siswa memiliki korelasi dengan kemampuan penalaran matematis siswa. Dengan nilai signifikansi sebesar 0,005, maka H0 ditolak.

Hasil penelitian yang didapatkan menunjukkan adanya hubungan yang signifikan dari kepercayaan diri terhadap kemampuan penalaran matematis siswa.

\section{Pembahasan}

Partisipasi aktif setiap siswa terlihat ketika siswa menyelesaikan masalah yang terdapat pada lembar soal siswa. Hasil yang diperoleh dari skor skala kepercayaan diri siswa menunjukkan bahwa terdapat hubungan yang signifikan dari kepercayaan diri terhadap kemampuan penalaran matematis siswa SMP.

Iswidharmajaya dan Agung (Syam \& Amri, 2017) mengatakan dengan kepercayaan diri yang cukup, seorang individu akan dapat mengaktualisasikan potensi yang dimilikinya dengan yakin dan mantap. Kepercayaan diri yang tinggi sangat berpengaruh dalam kehidupan seseorang, karena apabila seseorang memiliki kepercayaan diri yang tinggi, maka akan timbul motivasi, 
kreatifitas, dan rasa yakin dalam pengambilan keputusan. Sementara itu kurangnya kepercayaan diri akan menghambat potensi diri, sehingga ia akan menjadi seorang yang pesimis dalam menghadapi tantangan, takut dan ragu-ragu dalam menyampaikan gagasan serta bimbang dalam menentukan pilihan dan sering membanding-bandingkan dirinya dengan orang lain. Oleh sebab itu, rasa percaya diri harus dimiliki dan dikembangkan pada setiap siswa.

Menurut Fukuyama (Hendriana et al., 2017) empat cara yang bisa menumbuhkan rasa percaya diri pada siswa yaitu: pertama, pahami betul apa yang harus dilakukan dan membiasakan diri untuk menyelesaikan tugas dengan baik. Kedua, cari contoh orang lain dan amati cara kerjanya. Ketiga, cari dukungan dari orang lain atu lingkungan. Keempat, lakukan reinterpretasi terhadap tekanan, karena orang yang mempunyai kepercayaan diri pernah berkali-kali mengalami kegagalan, tetapi kemudian ia berhasil mengatasi rasa tekanan yang diderita akibat kegagalannya.

Penalaran dalam matematika dapat mengembangkan pandangan seseorang tentang suatu permasalahan. Seseorang yang memiliki kemampuan penalaran tinggi kemungkinan akan mempunyai persepsi yang berbeda terhadap suatu permasalahan bila dibandingkan dengan seseorang yang kemampuan penalarnya rendah. Seseorang dengan kemampuan penalaran akan mengalami kesulitan menghadapi permasalahan sehingga mempengaruhi kualitas belajar siswa yang akan berdampak pada rendahnya hasil prestasi belajar. Seseorang yang memiliki kepercayaan diri dan penalaran matematis yang baik akan mampu menyelesaikan soal yang lebih rumit, yang menuntut kemampuan untuk mengaitkan berbagai macam konsep matematis dalam berbagai bentuk representasi matematika, bukan hanya soal dalam konteks sederhana yang hanya memerlukan hafalan dan rumus.

Beberapa penelitian juga menunjukkan adanya pengaruh kepercayaan diri terhadap kemempuan penalaran matematis siswa. Sebagaiman hasil penelitian Kloosterman dalam (Rafianti, 2013) mengungkapakan bahwa keberhasilan dan kegagalan yang dicapai siswa kelas VII dipengaruhi oleh motivasi, kepercayan diri dan keyakinan akan usaha yang mereka lakukan dalam pembelajaran matematika. Sejalan dengan penelitian Kloostrmaan Penelitian yang dilakukan oleh Tarte \& Fennema (Rafianti, 2013) mengemukakan bahwa terdapat hubungan yang kuat antara sikap kepercayaan diri (self-confidence) dan kemampuan matematis siswa.

Berdasarkan hasil penelitian serta pendapat beberapa ahli tersebut maka dapat disimpulkan bahwa terdapat hubungan yang signifikan anatara kepercayaan diri terhadap kemampuan penalaran matematis siswa.

\section{KESIMPULAN}

Kesimpulan yang dapat diambil dari penelitian ini adalah terdapat hubungan yang signifikan antara kepercayaan diri dengan kemampuan penalaran matematis siwa.

\section{DAFTAR PUSTAKA}

Annisa, W. (2010). Metode Penelitian Korelasional. Retrieved January 28, 2018, from bintangkecilungu.wordpress.com/2010/10/31/metode-penelitian-korelasional-2/

Fitriani, N. (2016). Hubungan Antara Kemampuan Pemecahan Masalah Matematis dengan Self Confidence Siswa SMP yang Menggunakan Pendekatan Pendidikan Matematika Realistik. Jurnal Euclid. Jurnal Euclid, 2(2), 341-351. 
Hartono, Y. (2010). Pembelajaran Matematika Sekolah Dasar. Universitas Terbuka.

Hendriana, H., Rohaeti, E. ., \& Sumarmo, U. (2017). Hard Skills dan Soft Skills Matematik Siswa. Refika Aditama.

Hermawan, A. S., \& Hidayat, W. (2018). Meningkatkan Kemampuan Penalaran Matematik Siswa SMP Melalui Pendekatan Penemuan Terbimbing. JPMI (Jurnal Pembelajaran Matematika Inovatif), 1(1), 7-20.

Hidayat, W. (2017). Adversity Quotient dan Penalaran Kreatif Matematis Siswa SMA dalam Pembelajaran Argument Driven Inquiry pada Materi Turunan Fungsi. KALAMATIKA Jurnal Pendidikan Matematika, 2(1), 15-28.

Hidayat, W., \& Prabawanto, S. (2018, January). Improving students' creative mathematical reasoning ability students through adversity quotient and argument driven inquiry learning. In Journal of Physics: Conference Series (Vol. 948, No. 1, p. 012005). IOP Publishing.

Isnaeni, S., Fajriyah, L., Risky, E. S., Purwasih, R., \& Hidayat, W. (2018). Analisis Kemampuan Penalaran Matematis dan Kemandirian Belajar Siswa SMP pada Materi Persamaan Garis Lurus. Journal of Medives, 2(1), 107-116.

Jati, R. (2012). Tujuan pendidikan (Nasional \& Unesco). Retrieved May 14, 2018, from https://www.kompasiana.com/roko/tujuan-pendidikan-nasionalunesco_550fdbc4a33311c037ba7d35

Kadarisma, G. (2016). Improving Students' Logical Thinking Mathematic Skill Through Learning Cycle 5E and Discovery Learning. In Proceeding Of 3rd International Conference on Research Implementation Education Of Mathematics and Science. UNY.

Mikrayanti. (2016). Meningkatkan Kemampuan Penalaran Matematis melalui Pembelajaran berbasis Masalah. Suska Journal of Mathematics Education, 2(2), 97-102.

Putri, N. R., Nursyahban, E. A., Kadarisma, G., \& Rohaeti, E. E. (2018). Analisis Kemampuan Pemahaman Matematik Siswa SMP Pada Materi Segitiga dan Segiempat. JPMI (Jurnal Pembelajaran Matematika Inovatif), 1(2), 157-170.

Rafianti, I. (2013). Penerapan Model Pembelajaran Matematika Berbasis Multiple Intelligences untuk Meningkatkan Kemampuan Pemahaman Konsep, Penalaran Matematis dan Self Confidence Siswa MTs. Universitas Pendidikan Indonesia.

Rismawati, Y., Nurlitasari, L., Kadarisma, G., \& Rohaeti, E. E. (2018). Analisis Karakteristik Learning Obstacle Siswa SMP dalam Menyelesaikan Soal Bangun Datar. JPMI (Jurnal Pembelajaran Matematika Inovatif), 1(2), 99-106.

Sholihat, N. A. N., Hidayat, W., \& Rohaeti, E. E. (2018). PENGHARGAAN DIRI DAN PENALARAN MATEMATIS SISWA MTS. JPMI (Jurnal Pembelajaran Matematika Inovatif), $1(3)$.

Sumarmo, U., Mulyani, E., \& Hidayat, W. (2018). Mathematical Communication Ability and 
Self Confidence Experiment with Eleventh Grade Students Using Scientific Approach. JIML-Journal of Innovative Mathematics Learning, 1(1), 19-30.

Syam, A., \& Amri. (2017). Pengaruh Kepercayaan Diri (Self Confidence) Berbasis Kaderisasi IMM Terhadap Prestasi Belajar Mahasiswa. Biotek, 5(1), 87-102.

Tresnawati, T., Hidayat, W., \& Rohaeti, E. E. (2017). Kemampuan Berpikir Kritis Matematis dan Kepercayaan Diri Siswa SMA. Symmetry: Pasundan Journal of Research in Mathematics Learning and Education, 2(2), 39-45.

Yusdiana, B. I., \& Hidayat, W. (2018). ANALISIS KEMAMPUAN PENALARAN MATEMATIS SISWA SMA PADA MATERI LIMIT FUNGSI.JPMI (Jurnal Pembelajaran Matematika Inovatif), 1(3). 
